Journal of Siberian Federal University. Humanities \& Social Sciences 10 (2017 10) 1563-1572

\title{
Separated by a Common Language: \\ on the Usage of Idioms in British and American Electoral Discourse
}

\author{
Svetlana Y. Pavlina* \\ Nizhny Novgorod State Linguistic University \\ named after N.A. Dobrolyubov \\ 31a Minin Str., Nizhny Novgorod, 603155, Russia
}

Received 01.06.2017, received in revised form 27.09.2017, accepted 06.10.2017

This article investigates idioms that conceptualize complex political issues in electoral discourse. The material consists of examples from British and American electoral debates and speeches (2010-2016) which show that politicians employ idioms for the purposes of self-presentation and their opponents' criticism. Sharing a common language Americans and the British have different socio-political experience and culture, which manifests itself in idioms. The conceptual analysis of metaphors embedded in idioms reveals both common and culture specific features with regard to their manifestation in electoral discourses. The data show that the American discourse is characterized by the employment of metaphors that have mechanisms as their conceptual source and a very limited use of metaphors with the source domains Nature and Food. Moreover, the findings reveal that idioms used by British politicians are more diverse, thus more submodels are established within the source domains analyzed. Accordingly, British and American electoral discourses meet different stylistic requirements. The next stage of analysis deals with idioms modifications. The investigation reveals that a significant number of idioms undergo transformations in electoral discourse. Politicians attempt to tailor them to a political context thus enhancing their imagery. The most common type is expansion, while contraction of idioms is quite rare.

Keywords: idiom, electoral discourse, conceptual analysis, source domain, transformation.

DOI: 10.17516/1997-1370-0154.

Research area: philology.

\section{Introduction}

Political discourse aims at either gaining or retaining power, persuasion being its effective tool. Persuasion acquires special importance in the course of electoral campaigns that resemble battle fields when the aspirant leaders try to make themselves or their party's policies attractive to voters, using the strategies of self-presentation or political opponents' criticism. Electoral discourse is multifold, of all its forms electoral debates tend to be the most efficient way to appeal to potential followers. Televised debates have been an integral part of American presidential elections for almost half a century. Unlike in the

(C) Siberian Federal University. All rights reserved

* Corresponding author E-mail address: pavlina.svetlana@mail.ru 
US, the discourse genre of electoral debates is resent in Great Britain, where the first televised debates took place in 2010.

To achieve their goals politicians strive to get some response from the voters. As J. Charteris-Blake puts it: "They respond more effectively to messages that explain proposed actions with reference to familiar experiences; successful politicians are those who can develop their arguments with evidence taken from beliefs about the world around them. Messages become persuasive when they evoke things that are already known or are at least familiar" (CharterisBlake, 2005: 13).

Idioms are linguistic units that meet these criteria. They contain in a very condensed form the basic models of human perception of the world that can be seen as archetypes, "cementing" idioms imagery and permeating their semantics. Due to metaphors which form their backbone, idiomatic expressions possess great expressive and emotive power. Since metaphors contain both emotional and evaluative connotations, they help to achieve cognitive and emotional involvement, thus shaping people's beliefs, attitudes and values in a subtle, indirect way. Various political issues are often characterized through metaphors, for example, "Billy No Mates Britain" is a way chosen by Nick Clegg to express his views on Britain's disintegration with Europe (CleggFarage debate, March 26, 2014).

According to the linguoculturological approach to idiomatic expressions analysis, idioms have cultural connotations, thus studying them we can get a key to the understanding of a certain culture (Kovshova, 2009, 2014). As E. Sapir put it: "Language is becoming increasingly valuable as a guide to the scientific study of a given culture. In a sense the network of cultural patterns of a civilization is indexed in the language which expresses that civilization" (Sapir, 1949: 161).
Americans and the British are conventionally referred to as two cultures separated by a common language. It is logical to suppose that though some electoral discourse genres have become common on both sides of the Atlantic, the examination of political rhetoric can reveal some specific features that stem from differences in culture. So in this paper I want to explore idioms used by American politicians running for presidency and by British party leaders participating in Parliamentary elections. Based on the data selected from the texts of preelectoral speeches and electoral debates, my aim is to describe the conceptualization involved, first establishing source concepts typical of American and British data, then comparing and contrasting them.

Idioms tend to vary in their stability and often undergo some transformations that help them to fit a particular textual environment. So at the next stage of the research I aim to explore such transformations, establishing their basic types and revealing their cross-cultural similarities and differences.

The following discussion makes a further original contribution by advancing understanding of how our conceptualization of political issues is affected by culture.

\section{Background}

Idiomatic expressions are traditionally treated as a specific type of word combinations characterized by semantic integrity, structural unity and completely or partially transferred meaning. Rosemarie Gläser uses the term "phraseological unit" by which she understands “(...) a more or less lexicalized, reproducible bilexemic or polylexemic word group in common use, which has syntactic and semantic stability, may be idiomatized, may carry connotations, and may have an emphatic or intensifying function in a text" (Gläser, 1998: 125). 
In this paper such terms as idioms, idiomatic expressions and phraseological units are used interchangeably. The properties of idioms and their lexical meaning components became the subject of numerous researches (Gläser, 1998; Moon, 1998; Teliya, 2005).

According to the linguoculturological approach, idioms possess cultural connotation that can be treated as the manifestation of archetypes, certain culture codes. Thus idiomatic expressions are seen not only as linguistic but also as culture signs (Kovshova, 2009, 2014; Maslova, 2004, Teliya, 1999).

Idioms are also studied with the employment of psycholinguistic methods, which enables researchers to explore some mechanisms of idiom recognition and production (Cutting, Bock 1997; Gibbs, Nayak 1989).

Since idiomatic expressions are metaphorical, they, in Gibbs' words, “do not exist as separate semantic units within the lexicon, but actually reflect coherent systems of metaphorical concepts" (Gibbs 1997:142).

According to G. Lakoff and M. Johnson, apart from being a stylistic device, metaphor is a powerful means of human cognition (Lakoff, Johnson, 1980). Metaphor is perceived as a tool to conceptualize the world. As Gibbs put it: "Many concepts, especially abstract ones, are partly structured via the metaphoric mapping of information from a familiar source domain onto a less familiar target domain" (Gibbs, 1997: 141).

Considering metaphors in political discourse researchers underline their persuasive power, metaphors are employed as ideological devices that serve political aims and interests. To study the use of metaphors in political discourse they apply conceptual metaphor theory and establish a set of models that serve as basic schemata conceptualizing various aspects of political sphere (Charteris-Black, 2005; Musolff, 2006).
The analysis of source domains enables to establish cross-cultural differences in metaphorical conceptualization of political discourse. A. Musolff investigated structural aspects of source domains in metaphorical mapping using a bilingual corpus of British and German public debates about the European Union (Musolff, 2006). A similar approach has been adopted by E. Budaev to analyze metaphors used in Russian and American media discourse in reference to presidential elections (Budaev, 2009).

Idioms are also studied from the standpoint of their variation and transformation. They distinguish between "systemic variations" of idioms and their "creative modifications". The former can be regarded as contextual synonyms because they possess a common semantic marker (Moon, 1998). Transformations, on the contrary, are not lexicalized, they are produced by individual authors to achieve a certain stylistic effect. In the course of idiom transformation they can employ some playing with the literal and transferred meaning, which is always predetermined by the context. A number of researchers attempted to establish the transformation types, comparing creative and canonical forms of idioms (CharterisBlack, 1999; Burger et al., 1982; Stepanova, 2012).

\section{Data Collection and methodology}

For the purpose of this research, 18 electoral discourse texts were studied (9 British and 9 American texts respectively). The American discourse texts include 3 Barak Obama - Mitt Romney televised debates (2012), 3 Hillary Clinton - Donald Trump televised debates (2016), Donald Trump's speech in Gettysburg, Pennsylvania (October 26, 2016), Burnie Sanders Announcement speech (May 20, 2015), Hillary Clinton's DNC speech (July 26, 2016). The British data are based on 3 General Election 
Debates (2010), Opposition Party Leaders Debate (April 16, 2015), Seven Party Leaders Debate (April 2, 2010), Jeremy Paxman's live question and answer programme with David Cameron and Ed Miliband (March 27, 2010), David Cameron Manifesto speech (2015), Nick Clegg Manifesto speech (2015), Ed Miliband Manifesto speech (2015).

I employed the continuous sampling method to single out idioms, which then were subject to conceptual analysis. I also used linguistic methods of componential, contextual, contrastive and interpretative analyses.

\section{Discussion}

\section{Source concepts}

In electoral discourse politicians use metaphors mainly to present themselves or their parties as the best solutions or to criticize their opponents. Thus the key target concepts in given texts refer to the speaker's or his party's policies or their opponents' ones.

All idiomatic expressions were subdivided into semantically similar complexes that can be described as metaphorical models, on the bases of which some conceptual sources were established.

The comparison and contrast of British and American metaphorical models revealed the following common source concepts: SPORT, PLAY, HUMAN BODY, BUSINESS/ MONEY, NATURAL PHENOMENA, ARTEFACTS. These domains manifest a certain similarity of metaphorical comprehension of political issues in British and American electoral discourse, however, the further analysis established some submodels within each source domain that highlight nationally specific features.

The discourse manifestation of the source domain SPORT shows greater variability in the British data than in the American ones and reveals the following submodels:

\section{POLITICS IS BOXING:}

(1) That's one of the things that actually gives us the ability to punch above our weight in the world. It gives us influence in the world. (David Cameron)

\section{POLITICS IS CRICKET:}

(2) I actually worked for the man who was sent by Margaret Thatcher, would you believe it, to bat for Britain in Brussels. (Nick Clegg)

\section{POLITICS IS BASEBALL:}

(3) We stepped up to the plate and put the good of the country first even though it meant working with people we disagreed with. (Nick Clegg)

In American electoral discourse the only model discovered is POLITICS IS BASEBALL:

(4) We're going to speed up the process, big league, because it's very inefficient. But they're on line and they're waiting to become citizens. (Donald Trump)

Running for presidency Donald Trump used the big league idiom in various contexts, where the baseball term acquired its metaphorical meaning "the highest achievement".

Another common source concept is PLAY. Both British and American data contain the submodel POLITICS IS A CARD GAIM:

(5) And you know what, if fighting for affordable child care and paid family leave is playing the "woman's card", then deal me in! (Hilary Clinton)

However, the British politicians also employ other variations of the concept "play" when they compare their opponents' actions to the children's game "pass the parcel" and their own strenuous efforts to "jumping through hoops":

(6) So don't let them tell you that the only choice is between two old parties who have been playing pass the parcel with your government for 65 years now - making the same promises, breaking the same promises. (Nick Clegg)

The source domain HUMAN BODY is equally represented both in British and American 
electoral discourses. It is quite conventional to say that the country is "back to its feet again", that the opponents "wash their hands" rather than seek solutions, that people have "to keep their heads above water" or "work their heart out". Consequently, we may conclude that metaphors of body parts are quite universal, they are employed by British and American politicians to put a gloss on their own actions as well as to castigate their opponents.

Another important concept source is BUSINESS/MONEY. Some terms referring to accounting prove to be deeply rooted in electoral rhetoric. Politicians underline the importance of "balancing the books" and getting to the "bottom line". Apart from these commonalities the data reveal some culturally specific elements:

(7) There are MPs who flipped one property to the next, buying property, paid by you, the taxpayer, and then they would do the properties up, paid for by you, and pocket the difference in personal profit. They got away scot-free. (Nick Clegg)

In this context the metaphor "to get away scot-free" is used in the British parliamentary election of 2010 to criticize dodgy political rivals who avoid punishment. The original meaning of the word "scot" is "tax", correspondingly, "scotfree" means "avoiding paying taxes".

The examination of idioms with the source domain ARTEFACTS allows to establish some subsets specific for respective national discourse communities. One of the American electoral discourse peculiar features is the employment of metaphors that have mechanisms as their conceptual source:

(8) We are going to start the engine rolling again, because... right now, our country is dying at 1 percent GDP. (Donald Trump)

Data show that some political aspects are conceptualized in terms of NATURAL PHENOMENA. While this concept source is quite common in British electoral discourse ("to turn the tide", "to fall through the cracks", "at rock bottom" etc.), it is used rather sparsely by the American politicians.

(9) They're all chasing the same rainbows such as social cohesion, global warming, containing terrorism, and rightly so. (David Cameron)

(10) That was in large part because of tax policies that slashed taxes on the wealthy, failed to invest in the middle class, took their eyes off of Wall Street, and created a perfect storm. (Hillary Clinton)

Various aspects of British domestic and foreign policies are metaphorically seen as a ROAD. This metaphorical model is elaborate when politicians say that the economy is "stuck in the rut", when they describe migration as a "twoway street" and promise not to find easy ways and not to "cut corners". Consequently, "road" symbolizes action and achievement:

(11) Your decision made sure that the difficult choices needed to get us back on track were taken, but taken with compassion and a sense of fairness. (Nick Clegg)

(12) If you are trying to persuade people to invest trust again, which was Mary's question, into politicians, then it's just not good enough to just talk the talk and not walk the walk. (Nick Clegg)

Data show that idioms with the source domain ROAD are also employed by American presidential hopefuls. They describe some crucial moments metaphorically as a "fork in the road" and relations between the countries as a "onelane highway":

(13) Now, our jobs have been taken away, they've gone to Mexico, they've gone to so many other countries, it's a one-lane highway where they get the jobs, they get the factories, they get the money, and we get the drugs, and we get the unemployment, and it's going to change, believe me, and it's going to change fast. (Donald Trump) 
The analysis of British electoral discourse reveals idiomatic expressions with the source domain FOOD. Unrealistic proposals of political rivals are metaphorically viewed as "pie in the sky", poverty is presented as "bread line", scarce resources are described as lack of meat:

(14) Our public services cut to the bone; our communities divided; our shared British values of decency, tolerance and generosity cast aside. (Nick Clegg)

However, the examination of American discourse data establishes the absence of idioms with the source concept FOOD, which can be considered a culture specific feature of political aspects conceptualization in the course of presidential elections.

The comparison and contrast of the British and American data reveal some other crosscultural differences. The examination allows to establish a number of idioms which reflect some aspects of American culture.

(15) It's wrong to take tax breaks with one hand and give pink slips with the other. (Hillary Clinton)

The quoted passage from Clinton's Democratic National Convention speech contains the idiom "pink slip" which means "a notice of dismissal from one's job". It bears some reference to the time when Americans received such notices in pink envelopes, thus it is possible to conclude that the idiom "pink slip" has a cultural connotation.

(16) Brothers and sisters! Now is not the time for thinking small. Now is not the time for the same old - same old establishment politics and stale inside-the-belt-way ideas. (Burney Sanders)

In (16) the idiom "inside the belt way" stands for Washington, D.C., officials of the US federal government (with reference to Capitol Beltway, a ring road that encircles Washington, D.C.). Its imagery is based on typically American notions, when the politicians working within
Capitol Beltway are believed to be politically and socially out of touch with the rest of America. Consequently, it is possible to conclude that the idiom "within the Beltway" possesses cultural connotation.

As for the British data, they also contain idiomatic expressions that are predominantly used in British English and thus are culture specific. This group contains such idioms as "to punch above your weight", "to play pass the parcel".

It is of interest that some idioms used by British and American politicians have an identical form but they differ in their meanings. In American English if a proposal is "on the table", people are no longer discussing it at the moment, it is postponed or put aside for later consideration. "To table" something means "to shelve" it. In British English if something is "on the table", it is being discussed or considered. Notably, the idiom "to take something off the table" means "to make it no longer available" both in British and American English:

(17) They can take the diplomatic route and end their nuclear program or they will have to face a united world and a United States president, me, who said we're not going to take any options off the table. (Barak Obama)

Upon the whole, British politicians tend to use idioms more often to appeal to the electorate than their American counterparts. Moreover, the idiomatic expressions in British electoral discourse prove to be more diverse, thus more submodels can be established within the source domains analyzed. It is possible to conclude that while running for presidency American politicians appear to be more pragmatic and matter of fact, so British and American electoral discourses meet different stylistic requirements.

\section{Variability and transformation}

Although idioms are characterized by structural unity, they allow some degree of 
variability which means that one or several words can be substituted without any changes to the meaning of the idiom. Such variations are conventional and are normally recorded in idiomatic dictionaries.

The examination of the data allowed to single out the following variations: to put a lid on / to put a cap on; to carry one's weight / to carry one's load; to brush one's hands / to wash one's hands.

Unlike variations, which are firmly established, transformations of idioms possess some novelty as they aim at enhancing the stylistic effect of the utterance. They can be seen as creative adaptations of idiomatic expressions that give a new lease on life to the hackneyed phrases.

The data show that almost thirty per cent of idioms analyzed undergo some transformations. For the purposes of this research I applied Charteris-Black's classification (1999), since it proved to be logical and applicable to all examples of my database. Thus four main types of idiom transformation were established in the analyzed electoral discourses:

\section{- Substitution}

It means the replacement of one or several words of the idiom while the syntactic pattern remains unchanged. It is not normally difficult to restore the initial form of the idiomatic expression.

(18) I was so surprised to see him sign on with the devil. (Donald Trump)

In this excerpt from Clinton - Trump debate, Donald Trump speaks about B. Sanders's support of Hillary Clinton. He modifies the idiom "to make a deal with a devil", substituting the verbal component "to make a deal" for "to sign on". Thus the politician adapts the initial idiom to the political context, which helps to revive its imagery.

- Antonyms

This form of transformation results in the meaning opposite to the original one, thus a stale phrase acquires a new twist and attracts the listeners' attention as in:

(19) So much pain for so little gain. (Leanne Wood)

\section{- Contraction}

This type of transformation involves the omission of some part of the idiom, which is normally a verbal one:

(20) I have met so many people who had their life savings wiped out, who lost their homes, who are barely back with their heads above water. (Hillary Clinton)

\section{- Expansion}

When expansion is employed some new elements are inserted into the initial pattern, which increases its expressive value:

(21) Well, as an observer it would be impossible, I think, for Ed Miliband to be Prime Minister without Nicola Sturgeon's 35-40 MPs and that is something I think very deeply concerning to a lot of English voters, they are very, very worried about the Scottish tail wagging the English dog. (Nigel Farage)

In (21) expansion is achieved by adding attributes Scottish and English, which makes the phrase evaluative and expressive. The familiar idiom is aptly tailored to a specific political contexts of general elections, which helps to express Farage's views on his opponents' possible coalition in an original, quite persuasive way.

Alongside the four main types of transformation the data revealed one more form of idiom modification, which can be called Blending. It occurs when two idioms are mixed to build a new expression as in:

(22) He violates the red line in the sand, and he made so many mistakes. (Donald Trump)

In (22) Donald Trump combines two idioms "to violate the red line" and "to draw a line in the sand", thus creating a new modified idiomatic expression. 
As for the frequency of each type of transformation, the examination of the data reveals very few cases of idiom contractions, while expansion is clearly the most common form of transformation. Elliptical forms of idioms are widely used in media discourse, especially in the headlines, though they don’t seem quite suitable in political speeches. So it is possible to conclude that it is the genre that presupposes the choice of idiom transformation types.

It is also of note that modifications of four major types have equal distribution across British and American texts. As for blending, it is discovered only in Clinton-Trump debates. Its usage can be attributed to some speech peculiarities of Donald Trump and should hardly be considered culture specific.

\section{Conclusion}

Summing it up, it can be said that idioms used in British and American electoral discourses are an effective means of persuasion. Their conceptual analysis reveals both common and culture specific features. The peculiarities of the American electoral discourse are the employment of metaphors that have mechanisms as their conceptual source and a very limited use of metaphors with the source domains
NATURE and FOOD. At the same time the data show that both British and American politicians conceptualize various aspects of political life in terms of SPORT, PLAY and HUMAN BODY. It is of note, that idiomatic expressions used by British politicians tend to be more diverse, thus more submodels can be established within the source domains analyzed. It is logical to conclude that American politicians appear to be more pragmatic and matter-of-fact than their British counterparts, so British and American electoral discourses meet different stylistic requirements. The analysis also revealed the usage of idioms that reflect some aspects of American and British culture and history, thus it is possible to say that they possess cultural connotation.

The examination of the data also showed that a significant number of idioms undergo transformations in electoral discourse, since politicians attempt to tailor them to a political context to enhance their imagery. The most common type is expansion, while the data contain only isolated cases of contraction. Apparently, the genres of electoral debates and pre-electoral speeches predetermine the usage of full, rather than contracted forms of idiomatic expressions, while their expansion is necessary to fit a specific electoral context.

\section{References}

Budaev, E. (2009). Metaphors in political discourse: a cross-cultural perspective, In Vestnik Piatigorskogo gosudarstvennogo lingvisticheskogo universiteta [Vestnik of Pyatigorsk linguistic state university], 1, 18-21.

Burger, H, Buhofer A., Sialm A. (1982). Handbuch der Phraseologie. Berlin: Walter De Gruyter, $433 \mathrm{p}$.

Charteris-Black, J. (1999). The survival of English proverbs: a corpus-based account, In DeProverbio, 5(2).

Charteris-Black, J. (2005). Politicians and Rhetoric. The Persuasive Power of Metaphor. Basingstoke: Palgrave McMillan, 235 p.

Cowie, A. (1998). Phraseology: Theory, analysis, and applications. Oxford: Clarendon Press, 220 p.

Cutting, J.C., Bock, J.K. (1997). That's the way the cookie bounces: Syntactic and semantic components of experimentally elicited idiom blends, In Memory \& Cognition. 25, 57-71. 
Gibbs, R., Nayak, N. (1989). Psycholinguistic studies on the syntactic behavior of idioms, In Cognitive Psychology, 21, 100-138.

Gibbs, R., Bogdanovich, J., Sykes, J., Barr, D. (1997). Metaphor in Idiom Comprehension, In Journal of Memory and Language, 37, 141-154.

Gläser, R. (1998). The stylistic potential of phraseological units in the light of genre analysis, In Cowie A.(ed.), Phraseology: Theory, analysis, and applications. Oxford: Clarendon Press, 125-143.

Kovshova, M. (2009). Semantika I pragmatika fraszeologizmov (lingvokulturologicheskiy aspect) [The semantics and pragmatics of phraseologisms (linguoculturological aspect)], Avtoreferat dissertazii doctora filologicheskih nauk [PhD thesis]. Moscow, $48 \mathrm{p}$.

Kovshova, M. (2014). Sopostavitelnyi analiz frazeologizmov: lingvokulturologicheskii podhod [A Comparative analysis of phraseological units: the linguoculturological approach], In Fililogiya $i$ kultura [Philology and Culture]. 38(4), 115-120.

Lakoff, G., Johnson, M. (1980). Metaphors We Live by. Chicago: University of Chicago Press, 256 p.

Maslova, V. (2004). Lingvokulturologiia [Linguoculturology]. Moscow, 208 p.

Moon, R. (1998). Fixed Expressions and Idioms in English. A Corpus-based Approach. Oxford: Clarendon Press, 352 p.

Musolff, A. (2006). Metaphor scenarios in public discourse, In Metaphor and Symbol, 21(1), 23 38.

Teliya, V. (1999). Russkaia frazeologiia v kontekste kultury [Russian phraseology in the cultural context]. Moscow, $336 \mathrm{p}$.

Teliya, V. (2005). O fenomene vosproizvodimosti iazykovykh vyrazheniy [On the phenomenon of language expressions reproductuion], In Jazuk, soznaniye, kommunikaziya [Language, conscience, communication], 30, 4-42.

Sapir, E. (1949). Selected writings in language, culture and personality. Berkely: University of California Press, 318 p.

Stepanova, A. (2012). Russkaia fraseologiya: psykholingvisticheskiy aspect issledovaniya. [Russian phraseology: the psycholinguistic aspect of research]. Moscow, $124 \mathrm{p}$.

\section{Разделенные общим языком:}

\section{использование идиом в британском и американском}

политических дискурсах

С.Ю. Павлина

Нижегородский государственньй лингвистический университет им. Н.А. Добролюбова Россия, Нижний Новгород, 603155, ул. Минина, 31 а

Статья посвящена исследованию идиом, которые вовлечены в процесс концептуализации сложных политических аспектов в предвыборном дискурсе. Материалом исследования послужили тексты британских и американских предвыборных дебатов и предвыборных речей политиков (2010-2016), в которых идиомы используются для самопрезентации политиков или 
для критики оппонентов. Британцы и американџы имеют общзий язык, однако их общественно-политический опьт и культура различны, что и находит отражение в идиомах. В основе идиом лежат метафоры. Применение концептуального анализа позволяет обнаружить как общие, так и культурно-специфические черть в отношении использования идиом в предвыборном дискурсе. Согласно полученным данным, американский дискурс характеризуется употреблением метафор со сферой-источником «механизм», в то время как метафоры со сферой-источником «природа» и «еда» употребляются американскими политиками крайне редко. Кроме того, исследование показывает, что в ходе предвыборной кампании британские политики употребляют более разнообразные идиомы, чем их американские коллеги, что позволяет выделить несколько подмоделей в рамках каждой сферы-источника. Из этого следует, что британский и американский предвыборный дискурсы отличаются в плане экспрессивности. На следующем этапе исследования рассматривались модификации идиом. Согласно полученным результатам, в предвыборном дискурсе значительное количество идиом подвергаются трансформациям. Это вызвано тем, что политики пытаются обыграть их внутреннюю форму согласно заданному политическому контексту, делая идиомы более экспрессивными. Наибольшее распространение получает расширение идиом, в то время как их стяжение не характерно для предвыборного дискурса.

Ключевые слова: идиома, предвыборный дискурс, концептуальный анализ, сфера-источник, трансформация.

Научная специальность: 10.00.00 - филологические науки. 